\title{
Koyun Kırkımı Sırasında İnsanlara Bulaşabilecek Bakteriler ve Antibiyotik Dirençlilik Profillerinin Belirlenmesi
}

\author{
Mustafa Barış Akgül1, Gülşah Akgül², Özge Yılmaz³, Serpil Kahya Demirbilek³, \\ Nihat Şındak ${ }^{1}$, Ali Günaydın ${ }^{1}$ \\ ${ }^{1}$ Siirt Üniversitesi Veteriner Fakültesi Cerrahi ABD, Siirt, Türkiye \\ ${ }^{2}$ Siirt Üniversitesi Veteriner Fakültesi İ̧ Hastalıkları ABD, Siirt, Türkiye \\ ${ }^{3}$ Uludağ Üniversitesi Veteriner Fakültesi Mikrobiyoloji ABD, Bursa, Türkiye
}

Geliş Tarihi / Received: 16.10.2017, Kabul Tarihi / Accepted: 01.02.2018

\begin{abstract}
Özet: Bu çalışmada, koyun kırkımı sırasında insanlara bulaşabilecek bakteriler ve bu bakterilerin antibiyotik dirençlilik profilleri araştırıldı. Koyun kırkımı, koyunlarda yılın belirli dönemlerinde yapılması gereken rutin işlemdir. Kırkım sırasında kırkımı yapan personele birçok etken bulaşabilmektedir. Kırkım yapan kişinin vücudunda yara vb. açıklıklar varsa bu etkenler daha kolaylıkla bulaşma fırsatı bulmakta ve eğer bu etkenlerin antibiyotik dirençlilikleri de mevcut ise tedavisi güç hastalıklara yol açabilmektedirler. Koagülaz negatif stafilokoklar (KNS), daha önceden apatojen olarak kabul edilmelerine rağmen, yapılan çalışmalarla dirençlilik profilleri ve patojenitelerinin zarar verici boyutta olduğunun farkına varılmış etkenlerdir. Çalışmada, kırkım personelinin elleri, yüzü ve kırkım yapılan makastan svap örnekleri alınarak, kültürleri ve Kirby-Bauer disk diffuzyon yöntemine göre antibiyogramları yapıldı. Başlıca KNS ve bazı streptokok cinsi bakteriler izole ve identifiye edildi. İzole edilen 54 adet bakteri izolatında test edilen 26 antibiyotikten 20 tanesine karşı direnç tespit edildi, çoklu direnç yönünden ise 54 izolattan 5'i en az 4, 1'i en çok 9 adet antibiyotiğe karşı dirençli bulundu. Sonuç olarak, koyun kırkımı sırasında insanlara bulaşabilecek bakteriler içinde bulunan, zoonoz ve dirençlilik profilleri belirlenmiş olan bu bakterilerin, insan sağlığını tehdit edebileceği görüldü ve hayvanlara yapılacak tüm müdahalelerin kurallı ve kontrollü biçimde yapılmasının gerektiği sonucuna varıldı.
\end{abstract}

Anahtar kelimeler: Antibiyotik dirençliliği, koyun kırkımı, Stafilokok, insan sağlığı

\section{The Determination of Antibiotic Resistance Profiles and Bacteria Infected Humans During The Sheep Shearing}

\begin{abstract}
In this study, bacteria infected the humans during the sheep shearing and their antibiotic resistance was investigated. Shearing season is routine process must be done in sheep at times of year. During shearing, several microorganisms can infect the operator. If the operator has wound, bacteria can more easily infect this person. Also, if these bacteria have resistance to the antibiotics, they can lead to diseases that are difficult to treat. Coagulase negative Staphylococci (CNS) are in despite of accepted as non-pathogenic previously, studies about CNS realized that, they are pathogenic and resistant to antibiotic. In this study, swap samples taken from shearing person's hand, face and scissors were cultured and Kirby-Bauer disc diffusion antibiotic susceptibility tests were also performed. Mainly CNS and some Streptococcus genus bacteria were isolated and identified and also resistance profiles of these bacteria were investigated. Identified 54 bacteria were resistant to 20 of 26 antibiotics. If multi-resistance can be evaluated, 5 isolate were found resistant to minimum 4 antibiotics, one isolate was found resistant to 9 antibiotics. As a result, it has been seen that these bacteria which have zoonotic and resistance potentials that can be transmitted to humans during sheep shearing, can threaten human health. It was concluded that all the interventions to be done to animals were to be done in a regular and controlled manner.
\end{abstract}

Key words: Antibiotic resistance, sheep shearing, Staphylococcus, human health

\section{Giriş}

İnsanoğlunun en eski üretim faaliyetlerinden olan hayvancilık içerisinde önemli bir yer tutan koyun yetiştiriciliği, ülkelerin; coğrafi durumları, iklimleri, geleneksel üretim aktiviteleri, kültürel yapı ve endüstrilerine, yetiştirilen ırkların verim yönüne ve miktarına göre farklılıklar göstermektedir [36]. İlk insan topluluklarından bugüne kadar koyunlar sürekli insanın yanı başında bulunmuştur. Binlerce yıldan beri sütü, eti, yapağısı, derisi, gübresi ve postu ile insanların en önemli gereksinimlerini karşılayan koyunlar, 21. yüzyıl insanlarının hayatında da büyük rol oynamakta olan hayvanlardır [22]. 
Koyunculukta kırkım işlemi, dünyada yaygın olarak yılda 1 defa yapılmakla birlikte çok sıcak iklime sahip bölgelerde sicaklık stresini azaltmak için yılda 2 defa yapılır. Çoğu ülkede yapağı kalitesini arttırmak amaciyla ilkbahar ve sonbahar aylarında yılda 2 defa bu işlem gerçekleştirilmektedir. Ekstrem şartlarda bu işlem sıcaklık stresi ve yapağ 1 kalitesi göz önünde bulundurularak yılda 3 hatta 4 defa gerçekleştirilebilmektedir [2, 7].

Zoonoz hastalıklar hayvanlardan insanlara bulaşan hastalıklar olarak tanımlanırlar [32]. Halk sağlığını tehdit eden zoonozlar, önem verilmesi gereken hastalıklardır [30]. Zoonoz hastalıklar etiyolojilerine göre bakteriyel, viral, riketsiyal, helmintik, protozoal, artrapodik ve fungal zoonozlar olmak üzere 7 sinıfa ayrilmaktadırlar [12].

Sağlıklı insan vücudunda, kişiye zarar vermeden denge içinde yaşayan mikroorganizma toplulukları, normal mikrobiyal florayı oluşturur. Normal insan derisi bölgelere göre farklı oranda aerobik mikroorganizma barındırır. Normal flora, kalıcı ve geçici flora olmak üzere iki gruba ayrılır. Kalıcı flora, belirli bölgelerde ve belirli yaşlarda genellikle değişmeyen, kısa süreli ortamdan kaldırılırsa bile yeniden oluşabilen, genellikle sabit kabul edilen, süreklilik gösteren mikroorganizma topluluğudur. Geçici flora ise; çoğu hastalık oluşturmayan, bazen patojen olabilen ve belirli vücut bölgelerinde birkaç saatten birkaç haftaya kadar değişebilen sürelerde kalan mikroorganizma topluluğudur. Kalıcı flora üyeleri ortadan kaldırıldığında, geçici flora mikroorganizmaları kolonize olur, çoğalır ve hastalık yapıcı özellik kazanabilirler.

Geçici olarak yerleşen mikroorganizmalar kontamine araç ve gereçlerden insan eline bulaşarak derinin yüzey kısmına yerleşirler. Escherichia coli, Pseudomonas aeruginosa, Gram-negatif basiller geçici mikroorganizmalardandır. Propionibacterium'lar, Corynebacterium'lar gibi koagülaz-negatif stafilokoklar ise derinin üst tabakasında yerleşen ve daimi florayı oluşturan kalıcı mikroorganizmalardır [11].

Stafilokoklar insan ve hayvanların deri ve muköz membranlarında daimi ya da geçici flora olarak da bulunabilen, aynı zamanda bazı türleri patojen olan bakterilerdir. Koagülaz negatif stafilokoklar (KNS) ve koagülaz pozitif stafilokoklar (KPS) olarak ikiye ayrılırlar, ama ikisi de ciddi hayvan ve insan enfeksiyonlarına neden olan ve aynı zamanda antibiyotik direnci de bulunabilen bakterilerdir [16]. Streptokoklar da, stafilokoklar kadar önemli olan, yine hem normal florada bulunabilen, hem de firsatçı enfeksiyonlara neden olabilen bakterilerdir [6].

Bu çalışmanın amacı; koyunlarda kırkım işlemi öncesi ve sonrasında; kırkım makasında, personelin el ve burun bölgesinde bulunan bakteriyel floranın saptanmasıdır. Örnek alınan bölgelerin, kırkım işlemi sonunda hangi bakterilerle kontamine olduğu, bu kontamine bakterilerin zoonotik özellikleri ve dirençlilik profillerinin araştırılması amaçlanmıştır.

\section{Materyal ve Metot}

Çalışmanın hayvan materyalini Siirt Üniversitesi Keçi Araştırma ve Uygulama Merkezi (KEÇİMER)'nde 1-1.5 yaş arasında, aynı bakım ve beslenme koşulları altında barındırılan, toplam 10 adet Romanov ırkı koyun oluşturdu. Kırkım yapacak personel, işlem öncesinde el yıkama işlemi gerçekleştirmedi, herhangi bir hayvanla teması olmadı ve gün içerisinde başka kırkım yapmadı. Kırkım makası daha önceden herhangi bir kırkım işleminde kullanılmamış olup yeni alınd 1 ve kırkım öncesinde herhangi bir hayvana temas ettirilmedi. Kırkım esnasında makas değiştirilmedi.

\section{Örneklerin alınması}

Her bir numune için ayrı ayrı steril svap kullanılarak sırasıyla makasın keskin kenarlarının tamamına, kırkımı yapacak personelin sağ el içi, parmaklarına, burun bölgesi ve ön iç kısmına sürülerek kırkım öncesinde ilk örnekler alındı. Her kırkım işlemi tamamlandıktan sonra aynı şekilde örneklemeler gerçekleştirildi. Kırkım öncesi 3 örnek, kırkım işlemi sırasında 30 örnek ve toplamda 33 örnek alınd1. Alınan örnekler Stuart-transport medium (BD, Heildelberg, Germany) ile soğuk zincir altında 20 saat içerisinde Uludağ Üniversitesi Veteriner Fakültesi Mikrobiyoloji Anabilim Dalı'na gönderildi.

\section{Kültür}

Laboratuvarda, \%5 koyun kanlı agara (BD, Heildelberg, Germany) ekim yapılarak $37^{\circ} \mathrm{C}$ 'de 20 saat aerobik atmosferde inkübe edildi. 20 saat sonunda çok yoğun olarak ürediği görülen örneklerdeki koloniler 
tek tek incelenerek, farklı morfolojiye sahip koloniler, kanlı agarda tekrar tek koloni pasajı yapılarak 20 saat $37^{\circ} \mathrm{C}$ 'de inkübe edildi. Bu pasaj sonras1 tekrar karışık üreme gösteren kolonilere tek koloni pasaj işlemi bir kez daha uyguland1.

Elde edilen saf kolonilerden 1-2 koloni alınarak $1 \mathrm{ml}$ Tryptic Soy Broth ve \%10 gliserol içeren mikro tüplerinde, aynı örnekten en az 2 tane olmak üzere inokule edildi ve $-20^{\circ} \mathrm{C}$ 'de saklandı. Kolonilerin tür düzeyinde identifikasyonu, API STAPH ve API STREP (BioMerieux, France) tanımlama sistemi ile üretici firma kılavuzuna göre yapıldı.

\section{Antibiyotiplendirme}

Koagulaz negatif stafilokok izolatlarının antibiyotik direnç profilleri, Clinical and Laboratory Standards Institute (CLSI)'a göre Müller-Hinton agar (Difco) kullanılarak Kirby-Bauer Disk Difuzyon yöntemiyle belirlendi [9]. Test edilen 26 antibiyotik ve konsantrasyonlar1: Penicillin (P, 10 units, Oxoid CT0043B), Oxacillin (OX, $1 \mu \mathrm{g}$, Oxoid CT0159B), Ampicillin (AMP, $10 \mu g$, Oxoid CT0003B), Amoxicillin-Clavulanic acid $(30 \mu \mathrm{g})$, Kanamycin $(\mathrm{K}, 30 \mu \mathrm{g}, \mathrm{CT} 0026 \mathrm{~B})$ Gentamicin $(\mathrm{CN}, 10 \mu \mathrm{g}$, Oxoid CT0024B), Streptomycin (S, $10 \mu \mathrm{g}$, Oxoid CT0047B), Tobramycin (10 $\mu \mathrm{g})$, Tetracycline
(TE, $10 \mu \mathrm{g}$, Oxoid CT0053B), Oxytetracycline (OT, $30 \mu \mathrm{g}$, Oxoid CT0041B), Doxycycline (DO, $30 \mu \mathrm{g}$, Oxoid CT0018B), Enrofloxacin (ENR, $5 \mu \mathrm{g}$, Oxoid CT0639B), Ofloxacin (OFX, $5 \mu \mathrm{g}$, Oxoid CT0446B), Ciprofloxacin (CIP, $5 \mu \mathrm{g}$, Oxoid CT0425B), Erythromycin (E, $15 \mu \mathrm{g}$, Oxoid CT0020B), Azithromycin (AZM, $15 \mu \mathrm{g}$, Oxoid CT0906B), Clindamycin (DA, $2 \mu \mathrm{g}, \mathrm{CT} 0064 \mathrm{~B})$, Sulfamethoxazole-Trimethoprim (SXT, $25 \mu \mathrm{g}$, Oxoid CT0052B), Chloramphenicol (C, $30 \mu \mathrm{g}$, Oxoid CT0013B), Rifampicin(RD, $5 \mu \mathrm{g}, \mathrm{CT} 0207 \mathrm{~B})$, Quinupristin/dalfopristin (QD, $15 \mu \mathrm{g}, \mathrm{CT} 1644 \mathrm{~B})$, Mupirocin (MUP, $200 \mu \mathrm{g}, \mathrm{CT}$ 0523B), Novobiocin (NV, $5 \mu \mathrm{g}, \mathrm{CT} 0037 \mathrm{~B})$, Vancomycin (VA, $30 \mu \mathrm{g}$, CT0058B). Kontrol amaçlı olarak CLSI'da belirtilen E. coli (ATCC 25922) ve S. aureus (ATCC 25923) standart suşları kullanıld1 [9].

\section{Bulgular}

\section{Kültür}

Toplam 54 adet bakteri izole ve identifiye edilmiş ve farklı vücut bölgelerine göre dağılımları tablo 1'de sunulmuştur. İzole edilen bakterilerin çoğunu KNS oluşturmuş, bunlar dişında iki farklı bakteri Streptococcus porcinus ve Streptococcus sanguinus identifiye edilmiștir.

Tablo 1. Kırkım öncesi ve sonrasında farklı vücut bölgelerinden izole edilen bakteriler

\begin{tabular}{|c|c|c|c|c|c|c|c|c|c|c|c|}
\hline Kırkım öncesi & $\begin{array}{l}\text { İzole edilen } \\
\text { bakteriler }\end{array}$ & $\begin{array}{c}1 . \\
\text { kırkım }\end{array}$ & $\begin{array}{c}2 . \\
\text { kırkım }\end{array}$ & $\begin{array}{c}3 . \\
\text { kırkım }\end{array}$ & $\begin{array}{c}4 . \\
\text { kırkım }\end{array}$ & $\begin{array}{c}5 . \\
\text { kırkım }\end{array}$ & $\begin{array}{c}6 . \\
\text { kırkım }\end{array}$ & $\begin{array}{c}7 . \\
\text { kırkım }\end{array}$ & $\begin{array}{c}8 . \\
\text { kırkım }\end{array}$ & $\begin{array}{c}9 . \\
\text { kırkım }\end{array}$ & $\begin{array}{c}10 . \\
\text { kırkım }\end{array}$ \\
\hline \multicolumn{12}{|c|}{ Makas üzerinde izole edilen bakteriler } \\
\hline \multicolumn{12}{|l|}{ Üreme yok } \\
\hline & $\begin{array}{l}\text { Staphylococcus } \\
\text { kloosii }\end{array}$ & - & - & - & - & - & - & - & + & - & + \\
\hline & $\begin{array}{l}\text { Staphylococcus } \\
\text { sciuri }\end{array}$ & - & - & - & - & - & + & + & - & - & + \\
\hline & $\begin{array}{l}\text { Staphylococcus } \\
\text { warneri }\end{array}$ & + & + & + & + & - & + & + & - & - & + \\
\hline & $\begin{array}{l}\text { Staphylococcus } \\
\text { xylosus }\end{array}$ & + & + & + & + & - & - & - & + & + & + \\
\hline \multicolumn{12}{|c|}{ Eı Üzerinden İzole Edilen Bakteriler } \\
\hline \multirow[t]{4}{*}{$\begin{array}{l}\text { Streptococcus } \\
\text { acidominus }\end{array}$} & $\begin{array}{l}\text { Streptococcus } \\
\text { acidominimus }\end{array}$ & + & - & - & - & - & - & - & - & - & - \\
\hline & $\begin{array}{l}\text { Staphylococcus } \\
\text { kloosii }\end{array}$ & - & - & - & - & - & - & + & + & - & + \\
\hline & $\begin{array}{l}\text { Streptococcus } \\
\text { porcinus }\end{array}$ & + & + & + & - & + & - & - & - & - & - \\
\hline & $\begin{array}{l}\text { Streptococcus } \\
\text { sanguinus }\end{array}$ & - & - & - & - & + & + & - & - & - & - \\
\hline
\end{tabular}




\begin{tabular}{|c|c|c|c|c|c|c|c|c|c|c|c|}
\hline Kırkım öncesi & $\begin{array}{l}\text { Izole edilen } \\
\text { bakteriler }\end{array}$ & $\begin{array}{c}1 . \\
\text { kırkım }\end{array}$ & $\begin{array}{c}2 . \\
\text { kırkım }\end{array}$ & $\begin{array}{c}3 . \\
\text { kırkım }\end{array}$ & $\begin{array}{c}4 . \\
\text { kırkım }\end{array}$ & $\begin{array}{c}5 . \\
\text { kırkım }\end{array}$ & $\begin{array}{c}6 . \\
\text { kırkım }\end{array}$ & $\begin{array}{c}7 . \\
\text { kırkım }\end{array}$ & $\begin{array}{c}8 . \\
\text { kırkım }\end{array}$ & $\begin{array}{c}9 . \\
\text { kırkım }\end{array}$ & $\begin{array}{c}10 . \\
\text { kırkım }\end{array}$ \\
\hline & $\begin{array}{l}\text { Staphylococcus } \\
\text { sciuri }\end{array}$ & - & - & - & - & - & - & + & - & + & + \\
\hline & $\begin{array}{l}\text { Staphylococcus } \\
\text { warneri }\end{array}$ & + & + & + & + & - & + & - & - & + & + \\
\hline \multicolumn{12}{|c|}{ Burun Bölgesinden İzole Edilen Bakteriler } \\
\hline \multirow[t]{3}{*}{$\begin{array}{l}\text { Staphylococcus } \\
\text { capitis }\end{array}$} & $\begin{array}{l}\text { Staphylococcus } \\
\text { capitis }\end{array}$ & - & - & - & - & - & - & + & + & + & + \\
\hline & $\begin{array}{l}\text { Staphylococcus } \\
\text { kloosii }\end{array}$ & + & + & + & + & + & - & - & - & - & - \\
\hline & $\begin{array}{l}\text { Staphylococcus } \\
\text { sciuri }\end{array}$ & + & - & - & - & + & + & - & + & + & + \\
\hline
\end{tabular}

Tablo 2. İzole edilen bakterilerin antibiyotik dirençlilik profilleri ve oranları

\begin{tabular}{|c|c|c|c|c|c|c|c|c|}
\hline & $\begin{array}{l}\text { S. sciuri } \\
\text { (n: 12) }\end{array}$ & $\begin{array}{l}\text { S. capitis } \\
\text { (n: 5) }\end{array}$ & $\begin{array}{l}\text { S. kloosii } \\
\text { (n: 10) }\end{array}$ & $\begin{array}{l}\text { S. porcinus } \\
(\mathrm{n}: 4)\end{array}$ & $\begin{array}{c}\text { S. sanguinus } \\
\text { (n: 2) }\end{array}$ & $\begin{array}{l}\text { S warneri } \\
\text { (n: 14) }\end{array}$ & $\begin{array}{l}\text { S. xylosus } \\
\text { (n: 7) }\end{array}$ & $\begin{array}{c}\text { Ortalama } \\
\text { (n: 54) }\end{array}$ \\
\hline & $\begin{array}{l}\text { Say1 } \\
(\%)\end{array}$ & $\begin{array}{l}\text { Say1 } \\
(\%)\end{array}$ & $\begin{array}{l}\text { Say1 } \\
(\%)\end{array}$ & $\begin{array}{l}\text { Say1 } \\
(\%)\end{array}$ & $\begin{array}{l}\text { Say1 } \\
(\%)\end{array}$ & $\begin{array}{l}\text { Say1 } \\
(\%)\end{array}$ & $\begin{array}{l}\text { Say1 } \\
(\%)\end{array}$ & $\begin{array}{l}\text { Say1 } \\
(\%)\end{array}$ \\
\hline Oxacillin & $3(25)$ & $2(40)$ & $4(40)$ & $1(25)$ & - & $6(43)$ & $3(43)$ & 31 \\
\hline Penisilin G & $4(33)$ & $3(60)$ & $5(50)$ & $2(50)$ & $1(50)$ & $7(50)$ & $3(43)$ & 48 \\
\hline Ampicilline & $3(25)$ & $2(40)$ & $4(40)$ & $1(25)$ & - & $5(36)$ & $2(29)$ & 28 \\
\hline Metisillin & $2(17)$ & $2(40)$ & $3(30)$ & - & - & $3(21)$ & $4(57)$ & 24 \\
\hline Amox-clau asit & $4(33)$ & - & $1(10)$ & - & - & $1(7)$ & - & 7 \\
\hline Kanamisin & $1(8)$ & - & - & - & - & - & - & 1 \\
\hline Gentamycine & - & - & - & - & - & - & - & - \\
\hline Streptomycine & $2(17)$ & $1(20)$ & - & - & - & - & - & 5 \\
\hline Tobramycin & - & - & - & - & - & - & - & - \\
\hline Clindamycine & $1(8)$ & $1(20)$ & $1(10)$ & - & - & - & $1(14)$ & 3 \\
\hline Tetrasiklin & $8(67)$ & $3(60)$ & - & $3(75)$ & $1(50)$ & $2(14)$ & $4(57)$ & 49 \\
\hline Oxytetracycline & $9(75)$ & $3(60)$ & $1(10)$ & $3(75)$ & - & $2(14)$ & $5(71)$ & 54 \\
\hline Doksisilin & $6(50)$ & $2(40)$ & $1(10)$ & $2(50)$ & - & $1(7)$ & $7(10)$ & 30 \\
\hline Enrofloxasine & - & - & - & - & - & - & - & - \\
\hline Oflaksasin & - & - & - & - & - & - & - & 1 \\
\hline Ciprofloksasin & - & - & - & - & - & - & - & - \\
\hline Eritromycin & $2(17)$ & $1(20)$ & - & $1(25)$ & - & - & - & 7 \\
\hline Azitromycin & $2(17)$ & $1(20)$ & - & - & - & - & - & 7 \\
\hline Sulfa-trimeth & $2(17)$ & - & - & - & - & - & - & 2 \\
\hline Cefoksitin & $3(25)$ & $1(20)$ & - & - & - & - & $1(14)$ & 8 \\
\hline Cloramfenikol & - & - & - & - & - & - & - & - \\
\hline Rifampisin & $2(17)$ & - & - & - & - & - & - & 2 \\
\hline Mupirosin - & $1(8)$ & - & - & - & - & - & - & 1 \\
\hline Quinupristin/dalfopristin & $2(17)$ & - & - & - & - & - & - & 2 \\
\hline Vankomisin & - & - & - & - & - & - & - & - \\
\hline Novobiocin & $7(58)$ & $2(40)$ & $5(50)$ & $2(50)$ & $1(50)$ & $5(36)$ & - & 41 \\
\hline
\end{tabular}




\section{Antibiyotiplendirme}

Bakteri izolatların tümünde test edilen 26 antibiyotikten Gentamicine, Tobramicin, Enrofloxacin, Ciprofloxacin, Chloramphenicol, Vancomycin haricinde 20'sine karşı direnç bulundu. En yüksek direnç oranının Oxytetracycline (\%54), Tetracycline (\%49), Penicillin G (\%48) ve Novobiocin'e (\%41) karşı olduğu, test edilen diğer antibiyotiklerde bulunan direnç oranlarının ise azalan sırayla OX (\%31), DO (\%30), AMP (\%28), M (\%24), FOX (\%8), E, AZM ve AMC (\%7), S (\%5), DA (\%3), SXT, QD, RD (\%2), OFX, MUP, K (\%1) olduğu saptandı. Çoklu direnç (MDR) yönünden 54 izolattan 5'i en az 4 (AMP/E/N/P), 1'i en çok 9 adet antibiyotiğe karşı dirençli bulundu (Tablo 2).

\section{Tartışma ve sonuç}

Bu çalışmada; koyun yetiştiriciliğinin yoğun olduğu Siirt ilinde sağlıkl1 görünen bir koyun sürüsünün kırkım işlemleri sırasında; kırkım yapan personele, hangi tür etkenlerin bulaşabileceği ve bu etkenlerin antibiyotik direnç profilleri belirlenmesi amaçlanmiştır.

Türkiye'de küçükbaş hayvan yetiştiriciliğinde yılda 1-2 kez yapılan kırkımdan sonra herhangi bir sağlık kontrolü yapılmamaktadır. Dünya'da zoonoz hastalıkların sayısının gittikçe arttığı ve aynı zamanda bu hastalık etkenlerinin antimikrobiyal direncinde de büyük bir artış olduğu bilinmektedir. Çalışmamız sonucunda üreyen etkenlerin çoğunluğunu; özellikle, normal florada olarak düşündüğümüz etkenleri bir tarafa ayırdığımızda (burundan çalışma öncesi alınan örnekte üreyen Staphylococcus capitis, el üzerinde ilk örneklemede üreyen Staphylococcus acidominus vb.) KNS'ler oluşturmuştur. Önceki yıllarda apatojen olarak kabul edilen ancak sonradan üzerlerinde yapılan çok fazla çalışmayla KPS'ler kadar zararlı olabilecekleri ortaya çıkarılan KNS'ler, zoonoz ve firsatçı patojen olabilme özelliklerine sahip aynı zamanda birçok antibiyotiğe dirençli bakterilerdir [5, 16, 23, 28].

Örneğin; Staphylococcus kloosii, linezolid dirençliliğine sahiptir ve sepsis oluşturabilme özelliğine sahiptir [31]. Staphylococcus sciuri, hayvan izolatı olmasına rağmen insanlarda enfeksiyon oluşturabilir ve insanlarda oluşturabildiği bu enfeksiyonlara pek çok çalışmada rastlanmıştır $[10,24$, 26, 27, 34]. Staphylococcus sciuri; insanlarda en- dokardit, peritonit, septik şok, deri enfeksiyonları gibi birçok enfeksiyondan sorumludur [17, 18, 33, 37]. Ahoya ve ark. Staphylococcus sciuri enfeksiyonun kan enfeksiyonları içindeki oranı ve dirençlilik profili üzerinde yaptıkları çalışmada, izole edilen KNS'ler içerisinde Staphylococcus sciuri'nin büyük bir orana ve dirençliliğge sahip olduğunu bulmuşlardır [1].

S. warneri'nin sı̆ğrlarda ve insanlarda abort için bir neden olduğu öne sürülmüştür [4]. Aynı zamanda vertebral diskit [3], menenjit [20], ortopedik enfeksiyonlar [8], ventriküler şant enfeksiyonları ve endokardit [35] ile ilişkilidir. Ayrıca bir köpekte meningoensefalit vakasının nedeni olarak öne sürülmüştür [14]. Çalışmada identifiye edilen $S$. warneri izolatlarından biri 9 antibiyotiğge karşı dirençli izolat olarak bulunmuştur. Benzer şekilde Staphylococcus xylosus'da birçok endokardit, üriner sistem enfeksiyonları vb. enfeksiyonlardan izole edilmiştir [19, 28]. Aynı zamanda S. xylosus izolatlarının çoğu, nalidiksik asit, novobiocin ve penisilline karşı dirençli bulunmuşlardır [38]. Ayrıca; bazı S. xylosus izolatlar1 elastaz gibi virulens genlerine sahiptir ve bu gen insan IgA ve IgG'sine bağlanma özelliğine de sahiptir [5]. İdentifiye edilen diğer bir KNS olan Streptococcus sanguinus, firsat bulduğunda (diş temizleme ve ameliyatları) kan dolaşımına giriş yapabilir ve özellikle subakut bakteriyel endokarditin en sık nedeni olan kalp kapaklarını, özellikle de mitral ve aort kapaklarını kolonize edebilir [29].

Son kırkıma doğru aynı bölgeden alınan örneklerdeki bakterilerin, çok fazla artmayıp, bazı etkenlerin ilk örneklerde üreyip, sonra izole edilememesi aslında, örnek alımının tüm çalışmalarda olduğu gibi bu çalışmalarda da çok önemli olduğunu göstermektedir. Yine ilk örneklerde üreyip, sonradan üremeyen bakteriler, laboratuvar çalışmaları sırasında da, çok dikkatli olunması gerektiğini gösteren bir sonuçtur. Petrilerde ilk ekimde çok etken bir arada ve yoğun olarak ürediğinden, farklı kolonilerin ayırt edilmesinde zorluk çekilebilmektedir. $\mathrm{Bu}$ sorunun mikrobiyolojide en anlamlı çözümü, alınan örneklerin laboratuvara ulaştıktan sonra ilk bașta steril fizyolojik tuzlu su (FTS) içerisinde çözündürülmesi, sonra bu FTS'lerdeki etkenlerin sulandır1larak, sona doğru olan sulandırmalardan ekimlerin yapılmasıydı. Sonuçlar göstermektedir ki, normal floranın bulunduğu bölgelerden örnek alınarak ya- 
pılan çalışmalarda, yoğun üreme beklendiğinden bir sulandırma prosedürü kullanılması gerekmektedir.

Yapılan antibiyogram testi sonuçlarına göre, çoklu direnç (MDR) yönünden 54 izolattan 5'i en az 4 (AMP/E/N/P), 1'i en çok 9 adet antibiyotiğe karşı dirençli bulunmuştur (Tablo 2). Daha önce KNS'ler üzerinde yapılan çalışmalara baktığımızda, Güran ve ark. [14] KNS izolatlarının en az 2 antibiyotiğe dirençli bulmuşlar, hatta insanlarda firsatçı patojen olan S. saprophyticus izolatlarında çoklu antibiyotik direnci tespit etmişlerdir. Khordshed ve ark. [23] KNS üzerinde yaptıkları çalışmada benzer şekilde yüksek dirençlilik tespit etmişlerdir. Tüm bu artan dirençlilik profilleri, toksinleri nedeniyle zaten zararlı etkenler olan stafilokokların tedavisinin de zorlaşmasına yol açmaktadır. Özellikle hastane enfeksiyonlarında önemli bir yere sahip olan stafilokoklar, dirençlilik profillerinin de genişlemesi nedeniyle önemlerini artırmaya devam etmektedirler.

Çalışmada, burun bölgesinden alınan 30 örnekten $15(\% 50)$ 'inde stafilokok spp. üremiş ve bu izolatların \%52'si Penisillin G'ye karşı dirençli bulunmuştur. Gülbandılar [15], 3048 burun kültüründen izole ettikleri $217 \mathrm{~S}$. aureus'un \%91.4'ünü Penisillin G'ye karşı dirençli bulmuştur. Yağmur ve ark. [39] ise 203 sağlık çalışanının 43 (\%21.2) tanesinde $\mathrm{S}$. aureus burun taşı1ııılı̆̆ bu izolatların da sadece 2 'sinde (\%4.7) metisillin direnci bulmuşlardır. Bu sonuçlar özellikle metisillin direnci ve patojen etken saptanan kişilerin belirlenip tedavi edilmesi ve gerekirse işyerlerinde daha uygun başka bir bölümde çalıştırılması açısından önemlidir.

Stafilokokların, burunda taşınan en önemli etkenlerden biri olduğu, gelişmekte olan ülkelerde içerdikleri 14 farklı enterotoksinlerden dolayı besin zehirlenmelerinin en önemli nedenlerinden biri olduklar1 ve günümüzde neredeyse tüm stafilokokların sadece enterotoksinler değil birçok toksijenik yapıya sahip yapıları oldukları bilinmektedir [13]. Kahya ve ark. [21], 145 farklı KNS, KPS stafilokok izolatı üzerindeki yaptıkları çalışmada 145 izolatın hepsinde 1 yada daha fazla toksin geni tespit etmişlerdir. Bu sonuçlarla, günümüzde artık bilinmektedir ki, sadece KPS değil KNS'larda toksinler içermekte ve genişlemiş/genişleyen antibiyotik direncine sahip bulunmaktadirlar.
Hayvan tüy, deri gibi yüzeyleri üzerinde bulunan birçok etken, eski zamanlarda apatojen olarak değerlendirilirken, günümüzde artan antibiyotik dirençliliği vb. genetik çalışmalarla, bu apatojen görünen etkenlerin ciddi bir enfeksiyon kaynaği olduğu gösterilmiştir. Çalışmanın sonucunda; sağlıklı görünümlü hayvanlardan yapılsa da, hayvanlar üzerinde yapılan tüm işlem ve çalışmalarda, mutlaka gerekli önlemlerin alınması gerektiği ortaya çıkmıştır.

\section{Kaynaklar}

1. Ahoyo TA, Yehouenou Pazou E, Baba-Moussa L, Attolou Gbohou A, Boco M, Dramane KL, Aminou T, (2013). Staphylococcus sciuri outbreak at tertiary hospital in Benin. J Med Microb Diagn. 2, 126.

2. Aladaş A, (2013). Koyunlarda kırkım öncesi C vitamini ve humik asit uygulamasının kırkım stresini azaltmasındaki etkisinin incelenmesi. Yüksek Lisans Tezi, Afyon Kocatepe Üniversitesi Sağlık Bilimleri Enstitüsü, Afyon.

3. Announ N, Mattei J, Jaoua S, Fenollar F, Sati H, Chagnaud C, Roudier J, Guis S, (2004). Staphylococcus warneri'nin neden olduğu multifokal diskit. Eklem Kemik Omurgas1. 71, 240-242.

4. Barigye R, Schaan L, Gibbs PS, Schamber E, Dyer NW, (2007). Sığır kürtajının olası bir nedeni olarak Staphylococcus warneri'nin tanısal kanıtı. J Vet Diagn Invest. 19, 694-696.

5. Bedidi-Madani N, Greenland T, Yves R, (1998). Exoprotein and slime production by coagulase-negative staphylococci isolated from goats' milk. Vet Mic. 59, 139-145.

6. Bergey's manual of systematic bacteriology, (1984); Ørskov F. In N.R. Krieg. and Holt J.G. (eds): vol 1., Williams \& Wilkins, Baltimore, U.S.A. 420-423.

7. Cam MA, Kuran M, (2004). Shearing Pregnant Ewes to Improve Lamb Birth Weight Increases Milk Yield of Ewes and Lamb Weaning Weight. Anim Sci. 17, 1669-1673.

8. Campoccia D, Montanaro L, Visa L, Corazzari T, Poggio C, Pegreffi F, Maso A, Pirini V, Ravaioli S, Cangini I, Speziale P, Arciola CR, (2010). Ortopedik enfeksiyonlardan 26 Staphylococcus warneri izolatının karakterizasyonu. Int J Artif Organs. 33, 575-581.

9. CLSI: Performance standards for antimicrobial susceptibility testing; twentieth informational supplement, CLSI document M100-S20, Clinical and Laboratory Standards Institute, Wayne, PA, USA, 2010

10. Couto I, Sanches IS, Sa-Leao E., Lencastre H, (2000). Molecular characterization of Staphylococcus sciuri strains isolated from humans. J Clin Microbiol. 38, 1136-1143.

11. Demirbaş F, (2013). Piyasadan ve eczanelerden alınan çeşitli el dezenfektanlarının mikrobiyolojik etkilerinin karşılaştırılması. Bitirme Tezi, Erciyes Üniversitesi Eczacılık Fakültesi, Farmasötik Mikrobiyoloji Anabilim Dalı, Kayseri. 
12. Doğruer Y, (2000). Veteriner Halk Sağlığı ve zoonozlar. Veteriner Halk Sağlığı, Selçuk Üniversitesi Veteriner Fakültesi Yayın Ünitesi, Konya.

13. Erdoğan H, Araslan H, (2011). Otel personelinin burun ve boğaz kültüründe Staphylococcus aureus taşıyıcılığının araştırılması ve risk faktörlerinin irdelenmesi. Klimik dergisi. 24, 90-93.

14. Espino L, Bérmudez R, Fidalgo LE, González A, Miño N, Quiroga MI, (2006). Köpekte Staphylococcus warneri ile ilişkili meningoensefalit. J Küçük Animasyon Uygulaması. 47, 598-602.

15. Gülbandılar A, (2009). Kütahya yöresinde burun mukozasındaki Staphylococcus aureus taşıyıcılığının ve antibiyotik duyarlılığının araştırılması. Dumlupınar Üniversitesi Fen Bilimleri Dergisi, 18, 1-5.

16. Güran HŞ, Kahya S, (2015). Species diversity and Pheno-and Genotypic antibiotic resistance patterns of Staphylococci isolated from retail ground meats. J Food Scien. 80, 1291-1298.

17. Hedin G, Widerstrom M, (1998). Endocarditis due to Staphylococcus sciuri. Eur J Clin Microbiol Infect Dis. 17, 673-675.

18. Horii T, Suzuki Y, Kimura T, Kanno T, Maekawa M, (2001). Intravenous catheter-related septic shock caused by Staphylococccus sciuri and Escherichia vulneris. Scand J Infect Dis. 33, 930-932.

19. Hricak V, J Kovacik, P Marksc, D West, V Kromery, (1999). Aetiology and outcome in 53 cases of native valve staphylococcal endocarditis. Postgrad Med J. 75, 540-543.

20. Incani RN, Hernández M, Cortez J, González ME, Salazar YD, (2010). Strongyloides stercoralis hiperinfeksiyon ve lenfoma' li bir hastada stafilokok warneri menenjit: Bir vakanın ilk raporu. Rev Inst Med Trop Sao Paulo. 52, 169170.

21. Kahya S, Güran HŞ, Yılmaz Ö, (2016). PCR and ELISA for Staphylococcal enterotoxins and of some exotoxins from Staphylococcus spp. strains by PCR. Medycyna Weterynaryjna. 72, 28-33.

22. Kaymakçı M, (2010). İleri koyun yetiştiriciliği kitabı. Genişletilmiş 3. Baskı. İzmir, p.359.

23. Khorshed A, Özbal Y, (2012). Kan kültürlerinden izole edilen koagülaz negatif stafilokokların tiplendirilmesi ve antibiyotik duyarlılıklarının araştırılması. Sağlık Bil Derg. 21, 153-163.

24. Kloos WE, Ballard DN, Webster JA, Hubner RJ, Tomasz A, Couto I, Sloan GL, Dehart HP, Fiedler F, Schubert K, Lencastre H. de, Santos Sanches I, Health HE, Leblanc PA, Ljungh A, (1997). Ribotype delineationand description of Staphylococcus sciuri subspecies and their potential as reservoirs of metisillin resistance and staphylolytic enzyme genes. Int J Syst Bacteriol. 47, 313-323.

25. Koyuncu M, Taşkın T, (2013). Organik Küçükbaş Hayvan Yetiştiriciliği "Fırsatlar ve zorluklar". Türkiye II. Organik Hayvanc1l1k Kongresi. 24-26 Ekim 2013, Bursa, p.153-164.
26. Marsou R, Bes M, Boudouma M, Brun Y, Meugnier H, Freney J, Vandenesch F, Etienne J, (1999). Distrubition of Staphylococcus sciuri subspecies among human clinical specimens, and profile of antibiotic resistance. Res Microbiol. 150, 531-541.

27. Nagase N, Sasaki A, Yamashita K, Shimizu A, Wakita Y, Kitai S, Kawano J, (2002). Isolation and species distrubition of staphylococci from aniaml and human skin. J Vet Med Sci. 64, 245-250.

28. Orret FA, Shurland SM, (1998). Significance of coagulasenegative staphylococci in urinary tract infections in a developing country. Connecticut Medicine. 62, 199-203.

29. Paik S, Senty L, Das Sankar, Jody C.N, Cindy LM, Todd K, (2005). Identification of Virulence Determinants for Endocarditis in Streptococcus sanguinis by SignatureTagged Mutagenesis. Infect Immun. 73, 6064-6074.

30. Pappaioanou M, (2003). Veterinary medicine protecting and promoting lhe public's health and wellbeinq. Preven Vet Med. 1-11.

31. Peer MA, RA Nasir, DK Kakru, BA Fomda, G Bashir, IA Sheikh. Sepsis due to linezolid resistant Staphylococcus cohnii and Staphylococcus kloosii: first reports of linezolid resistance in coagulase negative staphylococci from India. Indian J Med Microbiol, 29, 60-62.

32. Slifko TR, Smith HV, Rose JB, (2000). Emerging parasite zoonoses associated with water and food. Int J Parasitol, 30, 1379-93.

33. Stepanovic S, I. Dakic, S. Djukic, B. Bozuk, M. SvabicVlahovic, (2002). Surgical wound infection associated with Staphylococcus sciuri. Scand J Infect Dis. 34, 685-686.

34. Stephanie N, Angeles Argudin M, Fessler AT, Hauschild T, Schwarz S, Butaye P, (2014). The ecological importance of the Staphylococcus sciuri species group as a reservoir for resistance and virulence genes. Vet Mic. 171, 342-356.

35. Stöllberger C, Wechsler-Fördös A, Geppert F, Gulz W, Brownstone E, Nicolakis M, Finsterer J, (2006). Bir immun yeterlilik hastasında lumbar disk protezi yerleştirildikten sonra stafilokok warneri endokarditi. J Infect. 52, 15-18.

36. Tuncer SS, (2008). Norduz ve Karakaş koyunlarında k1l folikülü ile yapağı özellikleri arasındaki ilişkiler. Doktora tezi, YYÜ, Fen Bilimleri Enstitüsü Zootekni ABD, Van.

37. Wallet F, Stuit L, Boulanger E, Roussel-Delvallez M, Dequiedt P, Courcol RJ, (2000). Peritonitis due to Staphylococcus sciuri in a patient on continuous ambulatory peritoneal disease. Scand J Infect Dis. 32, 687-698.

38. Vela J, Hildebrandt K, Metcalfe A, Remp el H, Bittman S, Topp E, Diarra M, (2012). Characterization of Staphylococcus xylosus isolated from broiler chicken barn bioaerosol. Poult Sci. 91, 3003-3012.

39. Yağmur G, İnci M, (2014). Sağlık çalışanlarında Staphylococcus aureus burun taşıyıcılığ 1 ve antibiyotik duyarlılığının araştırılması. Harran Üniversitesi Tıp Fakültesi Dergisi. 12, 31-37. 